\title{
Astronomical Observations During Willem Barents's Third Voyage to the North (1596-97)
}

\author{
SIEBREN Y. VAN DER WERF ${ }^{1}$
}

(Received 3 March 1997; accepted in revised form 26 November 1997)

\begin{abstract}
During Willem Barents's third voyage to the North and the wintering on Novaya Zemlya (1596-97), many astronomical observations were made. Solar declinations quoted in the diary of Gerrit de Veer indicate that the journal dates are correct within three days and that the Gregorian calendar was used throughout. The much-debated premature return of the sun on 24 January 1597, when it was geometrically below the horizon, fits many, but not all, of the characteristics of the arctic mirage that is now known as the Novaya Zemlya effect. This same effect might also explain the controversial report of a conjunction of Jupiter and the moon on 25 January 1597, when Jupiter would normally not have been visible. It is shown, however, that the occurrence of the conjunction during that night could have been concluded from following the positions of the moon and Jupiter for several hours. An analysis of latitude determinations made at the expedition's wintering place, Het Behouden Huys, indicates that typical measurements had an accuracy of $15^{\prime}-20^{\prime}$. In the Novaya Zemlya region, the variation of the earth's magnetic field was about $30^{\circ} \mathrm{W} 400$ years ago, and about $23^{\circ} \mathrm{E}$ in 1871 , and it is about $32^{\circ} \mathrm{E}$ today. During the return voyage in two open boats, Barents died on 20 June 1597. A reconstruction of that part of the route is presented. A Dutch-Russian expedition searched for Barents's grave in August 1995; however, it appears most likely that he was buried at sea.
\end{abstract}

Key words: Arctic, Novaya Zemlya, Willem Barents, Gerrit de Veer, wintering, Northeast Passage, astronomical observations, magnetic variation, Novaya Zemlya effect

RÉSUMÉ. Le troisième voyage de Willem Barents vers le Grand Nord et son hivernage en Nouvelle-Zemble (1596-97) ont donné lieu à de nombreuses observations astronomiques. Les déclinaisons solaires citées dans le journal de Gerrit de Veer indiquent que les dates du journal sont correctes à trois jours près et que le calendrier grégorien y a été utilisé de façon constante. Le retour prématuré du soleil le 24 janvier 1597, retour qui soulève tant de débats, cadre bien avec la plupart (mais pas toutes) des caractéristiques du mirage arctique que l'on connaît maintenant sous le nom d'effet de Nouvelle-Zemble. C'est ce même effet qui pourrait également expliquer le rapport controversé de la conjonction de Jupiter et de la lune le 25 janvier 1597, alors que Jupiter n' aurait pas dû être visible. Il existe cependant des preuves à l'effet qu'on aurait pu déduire l'existence de cette conjonction, cette nuit particulière, en suivant les positions de la lune et de Jupiter pendant plusieurs heures. Une analyse des mesures de latitude prises sur le lieu d'hivernage, Het Behouden Huys, révèle que les mesures typiques avaient une précision de $15^{\prime}$ à $20^{\prime}$. Dans la région de la Nouvelle-Zemble, la déclinaison du champ magnétique terrestre était occidentale il y a 400 ans (environ $30^{\circ}$ ) et orientale en 1871 (environ $23^{\circ}$ ). Aujourd'hui, elle est orientale (environ $32^{\circ}$ ). Barents mourut le 20 juin 1597, durant le voyage de retour qui s'effectuait dans deux embarcations non pontées. On présente une reconstruction de cette partie du voyage. En août 1995, une expédition russo-néerlandaise a cherché à retrouver sa tombe, mais il semblerait qu'il ait été inhumé en mer.

Mots clés: Arctique, Nouvelle-Zemble, Willem Barents, Gerrit de Veer, hivernage, passage du Nord-Ouest, observations astronomiques, déclinaison magnétique, effet de Nouvelle-Zemble

Traduit pour la revue Arctic par Nésida Loyer.

\section{INTRODUCTION}

On 20 June 1597, Willem Barents died, and only hours after him, so did another crew member, Claes Andriesz. The third attempt of the Dutch to find a northeast passage to China had failed. By the end of August 1596, their ship had become icebound on the east coast of Novaya Zemlya. The men were forced to spend the winter in a hut, Het Behouden Huys ("The Safe House" or "House of Safety"
[Beke, 1876]), which they constructed from driftwood found on the island and from the planking of their lost ship. In the summer of 1597,12 survivors of the original crew of 17 finally managed to reach the inhabited world in two open boats.

It had been the third attempt in three consecutive years: in 1594 , four ships had been sent, and in 1595, seven. On both voyages, Barents had been captain of one of the two ships from the city of Amsterdam, in a fleet commanded by Cornelis

\footnotetext{
${ }^{1}$ Kernfysisch Versneller Instituut, RijksUniversiteit Groningen, Zernikelaan 25, 9747AA Groningen, The Netherlands; vdwerf@kwi.nl

(C) The Arctic Institute of North America
} 
Cornelisz Nay. On the first voyage, the two ships from Amsterdam reached the Islands of Orange, just north of Novaya Zemlya, and returned from there. The other two ships entered the Kara Sea via Strait Vaygach and found it ice-free. During the second voyage, the effort was therefore entirely concentrated on Strait Vaygach. However, in 1595 the ice conditions were unfavourable, and they found the Kara Sea frozen. The Province of Zeeland and the city of Enkhuizen, which had provided ships for both voyages, lost interest but the city of Amsterdam decided to send two ships for a third attempt. Barents was chief pilot and acted as the scientific leader of this endeavour. Jacob van Heemskerck, who had been aboard with him in the year before, was now captain of his ship, while Jan Cornelisz de Rijp was captain of the other.

This time the passage would be attempted via high latitudes, as advocated by the influential theologian and cartographer Petrus Plancius. Disagreement between Barents and de Rijp arose when Barents wished to steer more easterly than Plancius had instructed. The strong-minded de Rijp insisted on a northerly course. The discovery of Spitsbergen and Bear Island during this part of the voyage should therefore be credited to him.

After a further disagreement about the course to steer, the two ships separated. De Rijp went north but returned in the same year. Barents and Heemskerck followed the coast of Novaya Zemlya and were forced to winter on its east coast. It was the irony of fate that a year later, after having struggled their way down along the icy west coast of Novaya Zemlya in two open boats, the survivors would run into de Rijp again at the Kola Peninsula and were able to return home with him.

Barents's name can be found in many spellings which indicate the patronymic: Barents (i.e., [son] of Barent), Barentsz (Barent's zoon [son]) and other versions. I shall use the first form, which is how he signed the letter left by the crew in Het Behouden Huys.

Barents's most important written work is his very elaborate "Caertboeck" (chart-book) of the Mediterranean (Barents, 1595), which also contains his own solar declination tables. His journals of the first two voyages have not survived. Among the many things that were found in Het Behouden Huys (De Jonge, 1872) is a book, now kept in the Rijksmuseum of Amsterdam, that most probably is his journal of the third voyage. It is in such a deplorable state, however, that its contents are completely inaccessible. Only very short extracts of his journals of the second and third voyages are available (Gerritz, 1924:80; l'Honoré Naber, 1917 [2]:237).

The only further written account of those voyages is the journal or diary of Gerrit de Veer, who was aboard Barents's ship on the second and third voyages and returned as one of the survivors. A young man, probably in his early twenties, and not among the highest in the ship's hierarchy, he had a rare narrative talent. His book, with the English title "The True and Perfect Description of three Voyages, so strange and woonderfull that the like hath neuer been heard before" (De Veer, 1598; Beke, 1876; l'Honoré Naber, 1917 [1]), contains the accounts of the three voyages and was soon translated into
French, English, German, and Italian. Because De Veer did not join the first voyage himself, it has been suggested that he may have had access to Barents's logbooks.

De Veer wrote his book after his return from the third voyage. It contains a wealth of astronomical observations and data on the magnetic variations in the arctic region of 400 years ago. The dates that he gives in the margins are, however, not always accurate. This inaccuracy led to criticism from his contemporaries and from the annotators of some later editions of his text (Beke, 1876; l'Honoré Naber, 1917 [2]). Indeed, it seems "strange and woonderfull" that after the winter night the sun would reappear about two weeks earlier than it should have. A mix-up of the Gregorian and the Julian day-counting has been suggested by some authors. It also is remarkable that De Veer reported seeing a conjunction of Jupiter and the Moon, when Jupiter must have been below the horizon.

This paper reanalyzes the day counting of De Veer's journal. Dates may be identified when a quoted solar declination is found in one or both of the tabulations that the expedition members used. We know that the expedition had Pedro De Medina's handbook (De Medina, 1545) in the Dutch edition (1580), but Barents also had his own tables, which were published in his "Caertboeck." There is evidence that the day-counting might have been correct in spite of the seemingly premature return of the sun.

Observations of the sun at times when it is geometrically below the horizon are possible, but rare. The effect has only recently been understood as a ducting phenomenon of light through multiple reflection against an inversion layer (Lehn, 1979; Lehn and German, 1981) and it has been named the "The Novaya Zemlya Effect." This paper will discuss to what extent De Veer's description fits the characteristics of the effect as we understand it today.

The conjunction between Jupiter and the Moon on 25 January 1597 is also re-analyzed. It is shown that it must have been perfectly possible for the explorers to conclude that the conjunction had occurred by following both Jupiter and the Moon for a number of hours, even if Jupiter would not have been visible at the very moment of the conjunction itself.

During their stay at Het Behouden Huys, Barents's crew took nine altitudes of the sun at meridian passage and two for stars, in order to find the latitude. Now that we know the latitude accurately, we can re-analyze these observations, taking into account computer-calculated declinations, astronomical refraction, and horizon dip. The results give information on the accuracy of Barents's measurements.

At the time of Barents's and Andriesz's deaths, on 20 June 1597, the men were somewhere near Ice Point, at the northwestern end of Novaya Zemlya. In the journal of Gerrit De Veer (De Veer, 1598; Beke, 1876; l'Honoré Naber, 1917 [1]) no mention is made of any burial ashore, in the ice, or at sea.

In August 1995, a Dutch-Russian expedition (Gawronski et al., 1997), organized on the Dutch side by the University of Amsterdam, unsuccessfully searched a stretch of the shore near Ice Point for a (double) grave. An attempt was made to reconstruct the route that Barents and his companions 
followed from the Islands of Orange to Cape Nassau, which they passed on 27 June. It is unlikely that a burial of whichever kind would have been postponed longer. During this part of the voyage, one altitude of the sun was measured, which is taken into account in the reconstruction.

\section{DATING THE JOURNAL: GREGORIAN VS. JULIAN CALENDAR}

A very interesting way to check the day-counting of De Veer's journal is provided by the declinations of the sun that are quoted in connection with altitude determinations. De Veer does not mention which tables were used, but in Het Behouden Huys a copy of Pedro De Medina's handbook (De Medina, 1545), in Dutch translation (1580), has been found. Barents also had his own tables, which had appeared shortly before in his "Caertboeck." The standard meridian for both tabulations was the meridian of Tenerife, and the declinations were given for four-year periods, the fourth year being a leap year. Both tabulations were based on the Julian calendar.

The Gregorian calendar, which was then ten days ahead of the Julian day-counting, had been introduced in 1582. While its use was dictated in the Catholic southern part of the Netherlands, which then also contained Flanders, some freedom was left in the northern provinces. It is understandable that the Dutch translation of De Medina's book would use the Julian calendar, because it was printed in 1580. It is, however, strange that Barents would still use it in his "Caertboeck," which came out in 1595.

The dating via declinations may be illustrated by the observation of 7 June 1596 (De Veer's journal date). There the sun's declination is given as $22^{\circ} 38^{\prime}$. Declinations were looked up from tabulations and used at face value to find, in combination with a measured altitude, the latitude. This procedure is described in the next section. The declination value of $22^{\circ} 38^{\prime}$ can be identified as taken from De Medina's tables for 5 June, Gregorian day-counting. The conclusion must then be that the date really was 5 June, according to their actual day-counting and not 7 June as later reconstructed by De Veer.

The sun's declinations mentioned by De Veer are given in Table 1. If the quoted value is recognized in either Barents's or De Medina's tables, the date from the table, transformed to Gregorian day-counting, is indicated in columns 3 or 4 . When a journal date is not found in either of the tables, which occurs in only five out of the twenty-three collected cases, the date adopted is taken as the one that gives the closest correspondence. From inspection of Table 1, it appears that during the first part of the voyage the tables of De Medina were used

TABLE 1. Identification of dates via the sun's declinations.

\begin{tabular}{|c|c|c|c|c|c|c|c|c|c|c|c|c|}
\hline \multicolumn{3}{|c|}{ Journal date } & \multirow{2}{*}{$\begin{array}{c}\text { Journal declination } \\
21^{\circ} 42^{\prime}\end{array}$} & \multicolumn{3}{|c|}{ Barents's tables ${ }^{1}$} & \multicolumn{3}{|c|}{ De Medina's tables ${ }^{2}$} & \multicolumn{3}{|c|}{ Adopted date ${ }^{3}$} \\
\hline 30 & May & 1596 & & & & & & & & 29 & May & 1596 \\
\hline 4 & Jun & 1596 & $22^{\circ} 17^{\prime}$ & & & & & & & 2 & Jun & 1596 \\
\hline 7 & Jun & 1596 & $22^{\circ} 38^{\prime}$ & & & & 5 & Jun & $1596^{4}$ & 5 & Jun & 1596 \\
\hline 19 & Jun & 1596 & $23^{\circ} 26^{\prime}$ & 16 & Jun & 1596 & 16 & Jun & 1596 & 16 & Jun & 1596 \\
\hline 23 & Jun & $1596^{5}$ & $23^{\circ} 28^{\prime}$ & & & & 23 & Jun & 1596 & 23 & Jun & 1596 \\
\hline 23 & Jun & $1596^{6}$ & $23^{\circ} 26^{\prime}$ & & & & & & & 23 & Jun & 1596 \\
\hline 30 & Jun & 1596 & $23^{\circ} 20^{\prime}$ & 30 & Jun & 1596 & 29 & Jun & $1596^{*}$ & 30 & Jun & 1596 \\
\hline 5 & Jul & 1596 & $22^{\circ} 53^{\prime}$ & & & & 4 & Jul & 1596 & 4 & Jul & 1596 \\
\hline 13 & Jul & 1596 & $21^{\circ} 54^{\prime}$ & 14 & Jul & $1596^{*}$ & 13 & Jul & 1596 & 13 & Jul & 1596 \\
\hline 17 & Jul & 1596 & $21^{\circ} 15^{\prime}$ & & & & & & & 17 & Jul & 1596 \\
\hline 21 & Jul & 1596 & $21^{\circ} 0^{\prime}$ & 20 & Jul & $1596^{*}$ & & & & 20 & Jul & 1596 \\
\hline 3 & Nov & 1596 & $-15^{\circ} 24^{\prime}$ & 4 & Nov & $1596^{*}$ & & & & 4 & Nov & 1596 \\
\hline 19 & Feb & 1597 & $-11^{\circ} 16^{\prime}$ & 19 & Feb & 1597 & & & & 19 & Feb & 1597 \\
\hline 2 & Mar & 1597 & $-7^{\circ} 12^{\prime}$ & 2 & Mar & 1597 & 2 & Mar & $1597^{*}$ & 2 & Mar & 1597 \\
\hline 11 & Mar & 1597 & $-3^{\circ} 41^{\prime}$ & 11 & Mar & 1597 & & & & 11 & Mar & 1597 \\
\hline 21 & Mar & 1597 & $0^{\circ} \quad 0^{\prime}$ & & & & & & & 20 & Mar & 1597 \\
\hline 2 & Apr & 1597 & $4^{\circ} 40^{\prime}$ & 1 & Apr & $1597^{*}$ & 1 & Apr & 1597 & 1 & Apr & 1597 \\
\hline 18 & Apr & 1597 & $11^{\circ} 12^{\prime}$ & 19 & Apr & 1597 & 19 & Apr & $1597^{*}$ & 19 & Apr & 1597 \\
\hline 28 & Apr & 1597 & $14^{\circ} 8^{\prime}$ & 28 & Apr & 1597 & & & & 28 & Apr & 1597 \\
\hline 10 & May & $1597^{5}$ & $17^{\circ} 45^{\prime}$ & 10 & May & 1597 & 10 & May & 1597 & 10 & May & 1597 \\
\hline 25 & May & 1597 & $20^{\circ} 46^{\prime}$ & 24 & May & 1597 & 24 & May & 1597 & 24 & May & 1597 \\
\hline 23 & Jun & 1597 & $23^{\circ} 30^{\prime}$ & 25 & Jun & 1597 & 7 & & & 25 & Jun & 1597 \\
\hline 24 & Jul & 1597 & $20^{\circ} 10^{\prime}$ & 24 & Jul & $1597^{*}$ & & & & 24 & Jul & 1597 \\
\hline
\end{tabular}

${ }^{1}$ Declination tables in Barents's Caertboeck.

${ }^{2}$ Declination tables in the Dutch translation of De Medina's Arte de Navigar, a copy of which was found in Het Behouden Huys.

${ }^{3}$ When a date cannot be positively identified from the tables of either Barents or De Medina, the date showing the nearest declination value is given.

${ }^{4}$ When corrected for a trivial misprint at this date.

${ }^{5}$ Midnight sun on the evening of the indicated date.

${ }^{6}$ From the only observation described in Barents's extract-journal.

${ }^{7}$ De Medina's tables had been left behind.

* Dates labeled with * occur in the tables, but under another year. 
more frequently than those of Barents. This changes around the end of July: from then on, all declinations except one agree with Barents's tables.

One notes that the adopted dates are close to the journal dates: the largest difference is three days. One must, however, keep in mind that De Veer wrote his book in final form only after his return. Given this agreement, it appears evident that the Gregorian calendar was used throughout. It has been said that Barents himself used the Julian calendar, as it would appear from his tables. However, his extract-journal of the third voyage (l'Honoré Naber, 1917 [2]:237; Gerritz, 1924:80) begins with a statement to the contrary: "Le 18 de May, stile neuve, nous sommons partis de Texel...," "stile neuve," or new style, referring to the new Gregorian way of counting days.

\section{METHODS OF ALTITUDE MEASUREMENT}

Sights of the sun and stars were taken at meridian passage with a marine astrolabe (Stimson, 1988) or with a cross-staff (Mörzer Bruyns, 1994), and occasionally with an astronomical ring. For one observation, made at Het Behouden Huys, an improvised instrument was used that consisted of a quadrant and a plumb line. The angle between the celestial body and the vertical is called the zenith distance, and its complement, the angle of the body above the horizon, is the altitude.

Latitude was obtained from the altitude at upper (south) meridian passage by the formula:

latitude $=$ zenith distance + declination $=90^{\circ}-$ altitude + declination

and for a sight of the midnight sun (lower meridian passage) by the formula:

latitude $=180^{\circ}-$ zenith dist - declination $=90^{\circ}+$ altitude - declination

The declination values that are quoted in De Veer's journal give no clear sign of any attempt to correct them for an estimated easterly longitude. For sightings of the midnight sun, the declinations were taken halfway in between two entries.

No corrections were made for astronomical refraction and horizon dip. Yet, the explorers did have an intuitive notion of this last correction: when on 3 November 1596, they could just see the upper limb of the sun above the horizon, De Veer wrote that "the land where we were was as high as the topsail of our ship" (De Veer, 1598:29). The land around Het Behouden Huys is just under $13 \mathrm{~m}$ above the sea (L. Hacquebord, pers. comm. 1996).

Horizon dip is to be applied for direct measurements of the altitude where the horizon is viewed, as is the case for the cross-staff. With an astrolabe, one measures the zenith distance and subtracts it from $90^{\circ}$ to find the altitude above the horizon. No correction for dip needs be made here, and neither does that correction apply to observations with the astronomical ring or the improvised quadrant-plumb line instrument.
Observations of the sun with an astrolabe are always made to give the altitude of its centre. With the cross-staff, measurements were most probably made for the upper limb, to protect the eye against the direct sunlight. It was known that in this case $16^{\prime}$ was to be subtracted for the sun's semidiameter (radius): on 19 February, a lower-limb observation was made with the self-constructed quadrant, and the correction is mentioned explicitly.

\section{ACCURACY OF THE LATITUDE DETERMINATIONS}

In order to get an idea of the accuracy of the latitude determinations, I re-analyzed those observations that were made at known positions, notably those taken at Het Behouden Huys, of which we now know the co-ordinates: $76^{\circ} 15^{\prime} \mathrm{N}$, $68^{\circ} 20^{\prime} \mathrm{E}$. These observations are given in Table 2.

Declinations can nowadays be obtained with great precision from planetarium programs in PC-version. This precision is much greater than that of the tables of Barents and De Medina. I used the program SkyMap (Marriott, n.d.) to find the declinations at local meridian passage on the corrected journal dates (see Table 1).

Corrections for astronomical refraction, including its dependence on temperature and atmospheric pressure, were taken from today's Nautical Almanac.

For observations that are assumed to have been made with a cross-staff, the horizon dip must also be subtracted from the observed altitude. At Het Behouden Huys, an eye-height of about $14.5 \mathrm{~m}$ is assumed, which gives a dip of 7'.

From these 12 observed altitudes $(\mathrm{N}=12)$, the average deviation of the observed altitude from the true altitude, $\overline{\Delta H}$, is determined:

$$
\overline{\Delta H}=\frac{1}{N} \sum_{i=1}^{N}\left(\Delta H_{i}\right)=+17.2^{\prime}
$$

A measure for the uncertainty of one single measurement is given by the standard deviation, $\sigma$ :

$$
\sigma=\sqrt{\frac{1}{(N-1)} \sum_{i=1}^{N}\left(\Delta H_{i}-\overline{\Delta H}\right)^{2}}=14.1^{\prime}
$$

If we consider only the nine altitude measurements of the sun taken at Het Behouden Huys, we find that $\overline{\Delta H}=+12.1^{\prime}$ and $\sigma=12.5^{\prime}$. If we further disregard the observations of 19 February and 10 May, where the altitude of the sun was very low, we get $\overline{\Delta H}=+6.3^{\prime}$ and $\sigma=5.1^{\prime}$.

When considering these observations made at Het Behouden Huys, and the deductions made by De Veer, one is struck by the fact that the latitude always comes out to be $76^{\circ}$ precisely. It is evident that these deductions were made backwards: quoting the altitude as precisely as $10^{\circ} 19^{\prime}(11$ March 1597) is clearly meant to give, in connection with the tabulated declination value of $-3^{\circ} 41^{\prime}$, the round figure of $76^{\circ}$ 
TABLE 2. Altitudes taken at known locations.

\begin{tabular}{|c|c|c|c|c|c|c|c|c|c|c|c|}
\hline 20 & Jul & $1596^{*}$ & 1 & Sun & $35^{\circ} 15^{\prime}$ & $-1^{\prime}$ & $-4^{\prime}$ & $35^{\circ} 10^{\prime}$ & $20^{\circ} 42^{\prime}$ & $75^{\circ} 32^{\prime}$ & $+32^{\prime}$ \\
\hline 14 & Dec & 1596 & 2 & Bellatrix & $20^{\circ} 18^{\prime}$ & $-3^{\prime}$ & $0^{\prime}$ & $20^{\circ} 15^{\prime}$ & $5^{\circ} 55^{\prime}$ & $75^{\circ} 40^{\prime}$ & $+35^{\prime}$ \\
\hline 19 & Feb & 1597 & 2 & Sun $^{6}$ & $3^{\circ} 16^{\prime}$ & $-16^{\prime}$ & $0^{\prime}$ & $3^{\circ} 0^{\prime}$ & $-11^{\circ} 14^{\prime}$ & $75^{\circ} 46^{\prime}$ & $+29^{\prime}$ \\
\hline 2 & Mar & 1597 & 2 & Sun & $6^{\circ} 48^{\prime}$ & $-9^{\prime}$ & $-7^{\prime}$ & $6^{\circ} 32^{\prime}$ & $-7^{\circ} 10^{\prime}$ & $76^{\circ} 18^{\prime}$ & $-3^{\prime}$ \\
\hline 11 & Mar & 1597 & 2 & Sun & $10^{\circ} 19^{\prime}$ & $-6^{\prime}$ & $0^{\prime}$ & $10^{\circ} 13^{\prime}$ & $-3^{\circ} 41^{\prime}$ & $76^{\circ} 06^{\prime}$ & $+9^{\prime}$ \\
\hline 20 & Mar & $1597 *$ & 2 & Sun & $14^{\circ} 0^{\prime}$ & $-4^{\prime}$ & $7^{\prime}$ & $13^{\circ} 49^{\prime}$ & $-0^{\circ} 8^{\prime}$ & $76^{\circ} 03^{\prime}$ & $+12^{\prime}$ \\
\hline 28 & Apr & 1597 & 2 & Sun & $28^{\circ} 8^{\prime}$ & $-2^{\prime}$ & $-7^{\prime}$ & $27^{\circ} 59^{\prime}$ & $14^{\circ} 10^{\prime}$ & $76^{\circ} 11^{\prime}$ & $+4^{\prime}$ \\
\hline 10 & May & 1597 & 2 & $\operatorname{Sun}^{7}$ & $3^{\circ} 45^{\prime}$ & $-14^{\prime}$ & $-7^{\prime}$ & $3^{\circ} 24^{\prime}$ & $17^{\circ} 45^{\prime}$ & $75^{\circ} 39^{\prime}$ & $+36^{\prime}$ \\
\hline 24 & May & $1597 *$ & 2 & Sun & $34^{\circ} 46^{\prime}$ & $-1^{\prime}$ & $-7^{\prime}$ & $34^{\circ} 38^{\prime}$ & $20^{\circ} 47^{\prime}$ & $76^{\circ} 09^{\prime}$ & $+6^{\prime}$ \\
\hline
\end{tabular}

${ }^{1}$ Location $1=$ Cross Islands, $76^{\circ} 4^{\prime}$ latitude from the British Admiralty chart. Location $2=$ Het Behouden Huys, $76^{\circ} 15^{\prime}$ latitude from a geographical positioning system.

${ }^{2}$ Taken from the Nautical Almanac for an adopted temperature of $-15^{\circ} \mathrm{C}$ and a pressure of $1030 \mathrm{mb}$.

${ }^{3}$ The values for horizon dip have been taken for an assumed eye height of $5 \mathrm{~m}$ at the Cross Islands. This observation was taken aboard the ship. The observations at Het Behouden Huys were made on land and an eye height of $14.5 \mathrm{~m}$ has been assumed. The sun's altitude of 11 March was taken with an astrolabe and needs no correction for dip. I assume that the other altitudes of the sun have been taken with a cross-staff. The observations of Bellatrix and Aldebaran were taken around mid-winter. The moon was down, and the horizon must have been invisible. I assume that an astrolabe has been used here.

${ }^{4}$ Declinations for the time of passage through the local meridian were determined with the computer program SkyMap.

${ }^{5}$ The error in the measured altitude is found as $\Delta \mathrm{H}=\mathrm{LAT}$ (chart) - deduced LAT.

${ }^{6}$ The sun's altitude on 19 February was taken with an improvised quadrant equipped with a plumb line. Thus the zenith distance was measured, and the measurement needs no correction for dip. This is the only observation of which it is explicitly stated that the lower limb was measured. The altitude is given as $3^{\circ}$, to which the semidiameter of $16^{\prime}$ must be added to obtain the altitude of the sun's centre.

${ }^{7}$ Midnight sun in the night of 10 to 11 May.

* Corrected journal date. See Table 1.

for the latitude. This data falsification causes the different observations to agree too well among each other, and this is reflected in the rather small values for the standard deviation of $12.5^{\prime}$ or even $5.1^{\prime}$.

The accuracy that can be reached with a cross-staff must be estimated to be about 20' (W.F.J. Mörzer Bruyns, 1994, pers. comm. 1996). Recently, the accuracy of a marine astrolabe has been estimated by a student class at the University of Groningen with a modern replica of a large astrolabe (diam. $250 \mathrm{~mm}$ ) modelled on the Dutch-made Skokloster-1 astrolabe from 1626 (Stimson, 1988:81). A series of 20 observations gave $\overline{\Delta H}=-3.0^{\prime}$ and $\sigma=15.2^{\prime}$. A smaller model, typically $200 \mathrm{~mm}$ in diameter, would have had a somewhat lesser accuracy. The astrolabe of Barents has not been preserved, and we do not know its dimensions. However, it seems reasonable to assume that his altitude measurements must have had a typical accuracy of 20 ' or less. One may guess why they wanted to see the same outcome for the latitude reconfirmed time and again. Was it the reassuring thought of being certain of their position?

\section{VARIATIONS OF THE EARTH'S MAGNETIC FIELD}

The first thing that catches the eye on De Veer's chart is that the northwest coastline of Novaya Zemlya is drawn nearly east-west, about $30^{\circ}$ off from its true direction. This difference has also been noted by the Norwegian Captain Elling Carlsen, who in 1871 discovered the remains of Het Behouden Huys (De Jonge, 1872). It is to be attributed to a local anomaly in the Earth's magnetic field: on 21 July 1596, Barents had found a magnetic variation of $26^{\circ}$ near the Cross Islands. The direction of this variation is not mentioned, but it is given as west in the annotations of S.P. L'Honoré Naber (1'Honoré Naber, 1917 [1]:59). Indeed, on his first voyage in 1594, and at nearly the same position, Barents had established a westerly variation of 2.75 points (1'Honoré Naber, 1917 [1]:7). A point is $11^{\circ} 15^{\prime}$ and refers to the commonly used compass, where the rose has 32 points as its finest subdivision (Davids, 1985). The measured variation was therefore about $31^{\circ} \mathrm{W}$.

On 10 May 1597, at Het Behouden Huys, the bearing of the midnight sun at its lowest point was found to be NNE (two points east) on a "common compass." The common or Dutch compass was compensated for an easterly variation of about half a point by mounting the rhumb cart rotated over this angle. The observed variation was therefore about 2.5 points or $\left(28^{\circ}\right) \mathrm{W}$. All these observations agree well among each other. The magnetic variation was evidently not taken into account in the construction of De Veer's chart.

Today, 400 years later, the magnetic variation in that region is about $32^{\circ} \mathrm{E}$. In 1871 , Carlsen found a magnetic variation of $23^{\circ} \mathrm{E}$. The average yearly change over the past 400 years is therefore $9.4^{\prime} \mathrm{E}$. Calculating on the basis of 
Carlsen's value, the change over the past 125 years has been $4.3^{\prime}$ per year, about equal to the yearly change of $5^{\prime} \mathrm{E}$ given on the British Admiralty Chart.

\section{RECONSTRUCTION OF THE ROUTE BETWEEN 16 AND 27 JUNE 1597}

Prior to the Dutch-Russian expedition to Novaya Zemlya in 1995, I had been asked to attempt a reconstruction of the route followed during Barents's return voyage and investigate if indications exist for sites where Barents and Andriesz might have been buried. This reconstruction, together with other elements from the present work, has been published in a book commemorating the 400th anniversary of the wintering (Van der Werf, 1996:93).

Figure 1, which is drawn after the British Admiralty chart 3182 from 1990, indicates the route from the Islands of Orange to Cape Nassau. The beginning and the end of this part of the route are known. The positions and times in between must be reconstructed as accurately as possible on the basis of De Veer's journal. One additional piece of information is the sun's altitude taken on 23 June near
Cape Comfort, according to De Veer's journal. The declination, quoted as $23^{\circ} 30^{\prime}$, is found in Barents's tables for 25 June and in De Medina's tables for 22 June. However, De Medina's tables had been left behind at Het Behouden Huys. It is quite possible that during this hectic phase of the voyage De Veer did not find much time for keeping up his diary, and a discrepancy of two days for the date on which he placed this event in his book after his return would not be too surprising.

For the sight reduction of this observation, the precise date is not important: the sun was near its solstice, and the computer-calculated declination at meridian passage is $23^{\circ} 29^{\prime}$ for 23 June or $23^{\circ} 27^{\prime}$ for 25 June. The sun's altitude was measured with an astrolabe as $37^{\circ}$, for which the astronomical refraction is $1^{\prime}$. The deduced latitude is then $76^{\circ} 30^{\prime} \mathrm{N}(23$ June) or $76^{\circ} 28^{\prime} \mathrm{N}$ (25 June), with an accuracy of about $20^{\prime}$. Cape Comfort (Mys Utesheniya) lies at $76^{\circ} 16^{\prime}$ on the British Admiralty chart. When we consider the distances given in De Veer's journal, it is not unlikely that this observation was taken at Mys Sakharova, which is more to the east and somewhat more to the north, at $76^{\circ} 19^{\prime}$ (see Fig. 1). The observation agrees with both locations, within the accuracy of the measurement.

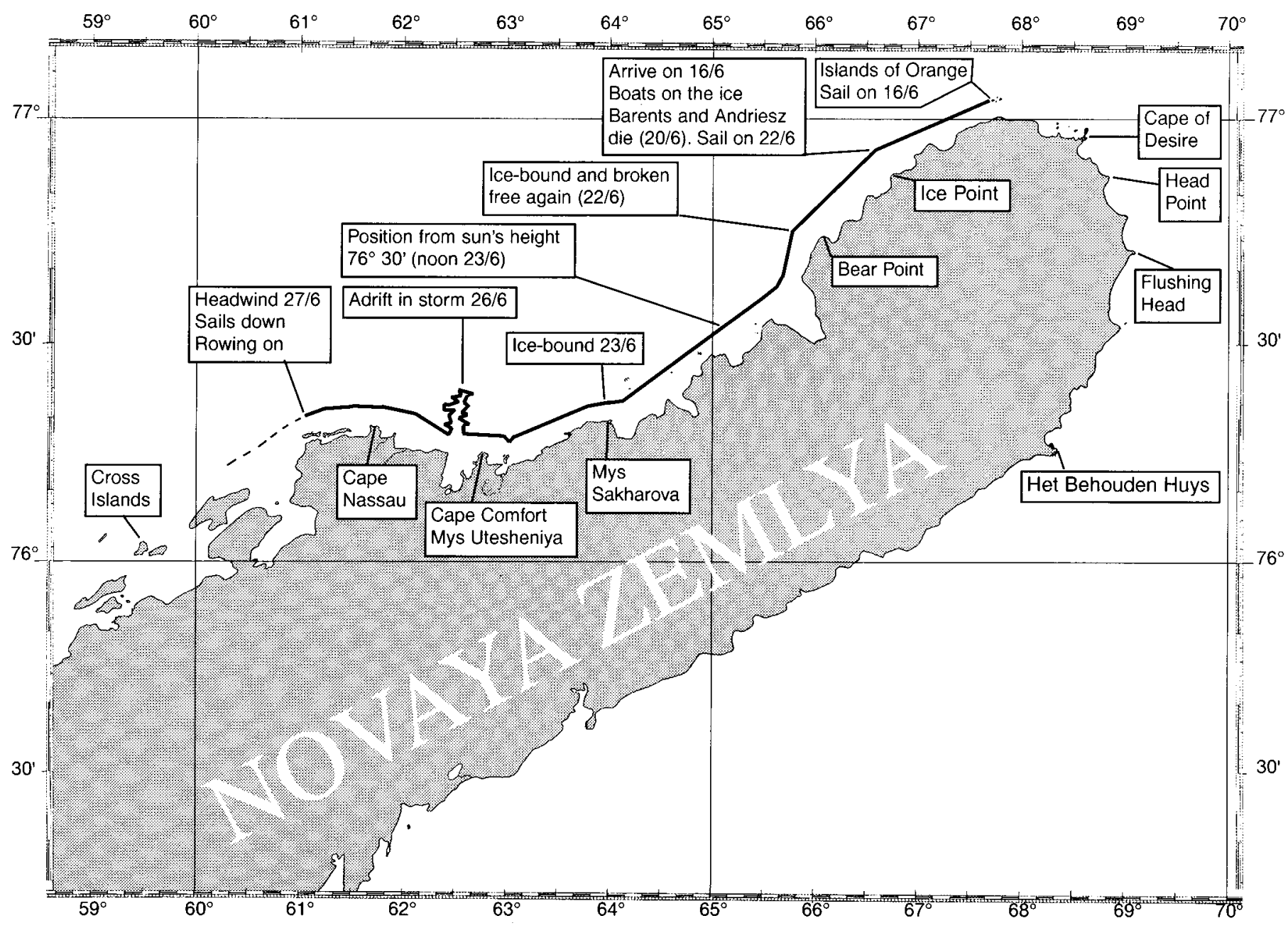

FIG. 1. The northern part of Novaya Zemlya drawn in accordance with the British Admiralty Chart 3182 from 1990, showing the reconstruction of the route on the home voyage from 16 June to 27 June 1597. 
For the rest of the reconstruction, one must rely on the distances and compass courses that De Veer quotes (Beke, 1876:200-203; l'Honoré Naber, 1917 [1]:138-139) and on the chart that was made on his instructions after their return (l'Honoré Naber, 1917 [1]:138).

All courses quoted by De Veer must be corrected for the observed variation of about $30^{\circ} \mathrm{W}$, because it is certain that they followed the coastline as much as possible.The covered distances were given in "Duytsche mylen," which is translated as "German miles" by some authors (l'Honoré Naber, 1917 [1]) and as "Dutch miles" by others (Beke, 1876). On De Veer's chart of Novaya Zemlya, one reads "Duytsche mylen 15 in een graedt (in one degree)." Barents, in his Caertboeck, gives on all charts also the Latin annotation "Miliaria Germanica quorum 15 uni gradui respondent," which shows that "German miles" is the proper translation.

According to the annotations of L'Honore Naber, the German mile was equal to 3725 Amsterdam fathoms, and would measure $6.3 \mathrm{~km}$ (l'Honoré Naber, 1917 [1]:71). However, the just-mentioned annotations of Barents and De Veer make it clear that the German mile equalled four nautical miles, and therefore measures $7408 \mathrm{~m}$.

The distances given in De Veer's diary are unreliable: they appear to be on average only about $60 \%$ of their quoted values. Therefore, relative distances have been used in the reconstruction, measured against the total distance from the Islands of Orange to Cape Nassau.

\section{POSSIBLE GRAVE SITES PAST ICE POINT}

On 22 June the surviving expedition members embarked from Ice Point in the early morning. Around mid-day, they found themselves blocked again by the ice. Later on the same day, they broke free and sailed on at a short distance from the coast. There is no mention of going ashore. They sailed on until they were once more surrounded by the ice on 23 June, near Cape Comfort. On this day, a meridian altitude of the sun was taken, which shows $76^{\circ} 30^{\prime} \mathrm{N}$ as their most likely position. Without having been ashore, they got free on the next day and tried to keep a course that would bring them past Cape Nassau. But about three German miles east of the Cape, they became icebound, close to land. Six of them went ashore to find wood. This is the first time since Barents and Andriesz died that there is a mention of going ashore. There was no other chance: on 25 June the wind was strong and they were afraid that the boats would drift off with the ice. This indeed happened: on 26 June, one of the boats floated seaward in a storm from the south. When the storm calmed down and the wind turned northwest, they managed to find the other boat, whose crew had gone ashore again to find wood.

Finally, on 27 June, they passed Cape Nassau. It was then one week after Barents and Andriesz died. Except for Ice Point itself, the only possible place for a grave on land seems therefore the landing places of 24 and 26 June, three German miles east of Cape Nassau.

\section{IS THERE REALLY A GRAVE?}

Seventeen men arrived at IJshaven (Ice Harbour, the location of Het Behouden Huys) and wintered there. Only 12 of them returned. The carpenter died during the construction of Het Behouden Huys on 23 September 1596, and was buried in a cleft in the rocks on the next day. Another man, whose name is not mentioned, died on 26 January 1597. De Veer describes how they made a grave in the hard snow, digging in turns because of the extreme cold.

It is remarkable that De Veer mentions nothing of either a grave on land or a burial at sea for Barents and Andriesz. Two weeks after their death, another man, Frans van Haerlem, died near the Cross Islands. De Veer's diary makes no mention of his burial on land or at sea, either.

On 18 June, two days before Barents's and Andriesz's death, some crew members, wanting to collect seabirds' eggs, had made an unsuccessful march to land. The excursion had not been without danger: on the way back, they sank through the ice. It therefore seems unlikely that, weakened as they were by hardship and scurvy, they would have tried to make the trip again with the two bodies. Moreover, the land was probably still frozen solid, and the digging of a grave would have been virtually impossible.

The possibility of a grave near Cape Nassau, at the landing place of 24 June, is of no more than hypothetical value. De Veer describes how they went ashore to find wood. If they had buried Barents and Andriesz there, why would he not have mentioned it? Most likely their bodies were committed to the deep near Ice Point, directly after their death. One may guess that it was on grounds of decency and respect for the deceased that De Veer is silent here: they could not bury them on land, and did not even have the means for a proper burial at sea, but were forced simply to leave them behind.

\section{THE MOON-JUPITER CONJUNCTION OF 25 JANUARY 1597}

The expedition members realized the danger of losing track of the proper day-counting during the polar winter. When three men, among them De Veer and Heemskerck, claimed to have seen a glimpse of the sun on 24 January, Barents did not believe them, saying that the sun would not appear until two weeks later. It has been pointed out above that De Veer used the Gregorian calendar throughout. Barents used the Julian calendar for his declination tables, but his extract-journal (1'Honoré Naber, 1917 [2]:237; Gerritz, 1924:80) is in Gregorian day-counting. The difference was ten days at that time. Some authors have suggested that De Veer, by exception, used the Julian calendar here, and that the date would thus be 3 February in Gregorian counting. If this had been so, Barents would not have objected, or at least not so strongly, and the whole exercise of verifying the date by observing the conjunction of Jupiter and the Moon would not have been necessary. 
The time of the conjunction of Jupiter and the Moon could be obtained from the Ephemeridae of Iosephus Scala (Scala, 1589). L'Honoré Naber erroneously identifies Scala with his more famous contemporary, the writer Josephus Justus Scaliger (1550-1609). Iosephus (Giuseppe) Scala was an astronomer, and he died at the early age of 29 , in 1584 , before the publication of his life work. Scala's Ephemeridae is a compilation of ecliptic longitudes for the sun, the moon, and a number of planets for the period 1589-1600. It also gives conjunctions and oppositions in the apparent time at the meridian of Venice.

The ecliptic is subdivided into twelve $30^{\circ}$ intervals, each corresponding to a sign of the zodiac. On 21 March, the sun is found at $0^{\circ}$ in Aries. When De Veer writes that the sun is expected to be seen again when it would be "at the 16th degree and 27th minute in Aquarius," he uses precisely Scala's terminology. The ecliptic longitude would then be $360^{\circ}-2 \times$ $30^{\circ}+16^{\circ} 27^{\prime}=316^{\circ} 27^{\prime}$, and the date would be 5 February. The plain irritation that L'Honoré Naber shows about what he calls "an utterly strange way of phrasing" (l'Honoré Naber, 1917 [1]:100) is not justified.

With the help of the computer programs SkyMap and CyberSky (Schimpf, n.d.), it is easily verified that the ecliptic conjunction must have occurred on the morning of 25 January at 00:14 UTC and the azimuthal conjunction, seen from Het Behouden Huys, at 02:30 UTC. Figure 2 shows the sky from 22:00 UTC on 24 January until 05:00 UTC on 25 January. The local time is 4 hours and 33 minutes ahead of UTC. The figure shows that Jupiter passes the moon on the low side.

Jupiter was geometrically below the horizon at the times of both conjunctions: its altitude was $-2^{\circ} 2^{\prime}$ at the time of the ecliptic conjunction and $-1^{\circ} 40^{\prime}$ when the azimuthal conjunction took place. De Veer and Heemskerk were violently criticized after their return, most of all by Robert Robertsz, professor in the theoretical art of navigation, in the first place because they insisted that they had seen the sun on 24 January, but also because they could not have seen the conjunction.

Ch.T. Beke has tried to find an explanation for both feats in a possible anomaly in the astronomical refraction of light: "Owing to the particular condition of the atmosphere, there existed an extraordinary refraction, not merely on the 25th of January, but continuously during fourteen days afterwards, at first amounting to nearly four degrees, but gradually decreasing to about one degree and a half." But he admits immediately: "The problem is a curious, and, with our still insufficient knowledge of the laws of atmospheric refraction in high latitudes, a difficult one" (Beke, 1876:clv).

The Frenchman M. Baills (quoted in l'Honoré Naber, 1917) has proposed a total reflection against higher (and during the winter, warmer) air layers. As will be discussed in the following section, this explanation comes close to our present understanding of the effect.

L'Honoré Naber discusses all these arguments pro and contra extensively in part II of the Linschoten edition
(l'Honoré Naber, 1917 [2]:83-126) before giving as his own conclusion that De Veer must have been telling stories. However, soon after the conjunction, Jupiter reappeared above the horizon, as shown in Figure 2, and it had then passed the Moon. Have the critics failed to see this point? Despite the fact that the conjunction itself might not have been observed, it was perfectly well possible for the expedition members to conclude by interpolation that it had taken place. There is no need to invoke any special atmospheric condition here.

De Veer writes that the conjunction took place during the night of 24 January at 6:00 a.m. (i.e., local time). I take it that he indeed meant the morning of 25 January. From his text it appears that he claims that both Jupiter and the moon were visible at the time of the conjunction (De Veer, 1598:35; Beke, 1876:146; l'Honoré Naber, 1917 [1]:101). I give my own translation: "For we looked constantly at the two planets (and saw) that they gradually approached each other until the moon and Jupiter stood just one above the other, both in the sign of Taurus, and this at six o'clock in the morning. At that time Jupiter and the moon were conjunct, in [the direction] north by east [i.e., one point east] on the compass at our house and the south of our compass was SSW, there was the true south, the moon being eight days old."

As mentioned above, the compass was a "common" Dutch compass, compensated for an easterly variation of half a point. The local variation had been established as about 2.5 points west, and this confirms that the true south was read as two points west of south, or SSW. The compass direction of one point east of north was therefore in reality one point west of the true north, which is a bearing of $348^{\circ} 45^{\prime}$. This is strikingly accurate: the ecliptic conjunction is calculated to have occurred at $347^{\circ} 28^{\prime}$.

De Veer's phrasing that the moon and Jupiter "stood one above the other" has led to the suggestion that he meant a conjunction in azimuth (l'Honoré Naber, 1917 [2]:101). However, this conjunction occurred later, at 2:30 UTC at a true bearing of $19^{\circ} 22^{\prime}$. If both planets were visible, the occurrence of the ecliptic conjunction would have been best identified as the situation where Jupiter would be in line with the two points of the moon, which was just past its first quarter.

Scala placed the conjunction at 01:00, which is quite accurate: with the help of CyberSky one finds 00:14 UTC, equivalently to 01:03 mean Venetian time, or 00:50 apparent Venetian time. From the age of the moon, De Veer estimated that the sun would be in the east and that the local time at Het Behouden Huys should thus be 6:00 a.m. Therefore they concluded that their local time was five hours ahead of Venice, and hence that their longitude was $75^{\circ}$ east of Venice. The true difference is $57^{\circ}$.

The details that De Veer gives and their accuracy are puzzling since, as mentioned above, Jupiter was geometrically far enough below the horizon to make it invisible under normal circumstances, at the time of both the ecliptic and the azimuthal conjunctions. 


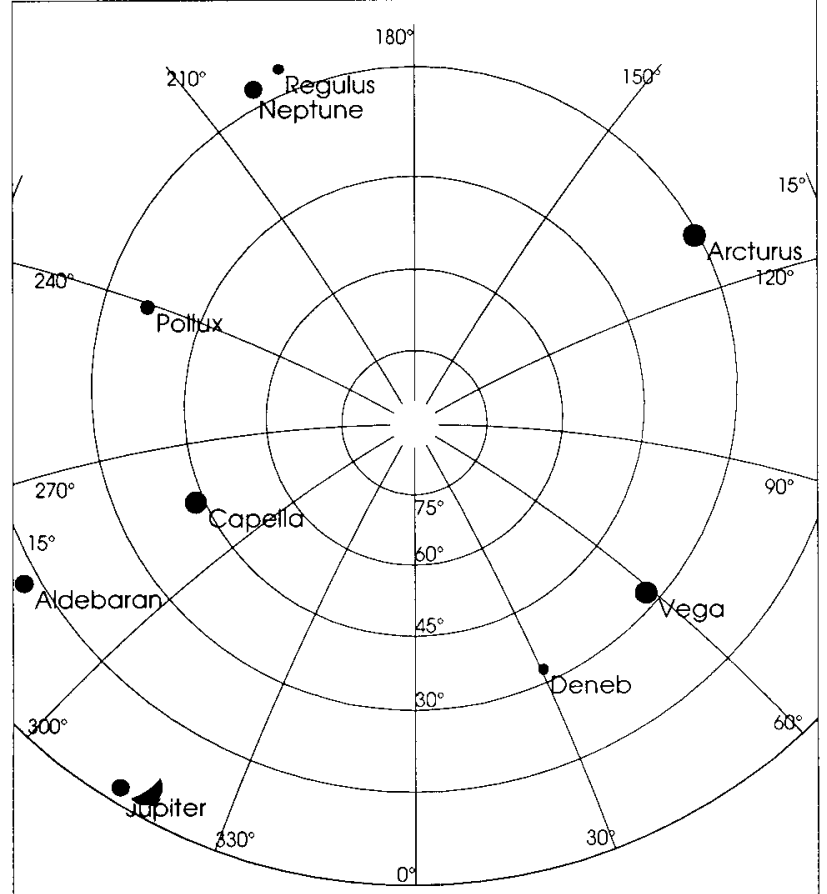

24JAN97 22.00 UTC
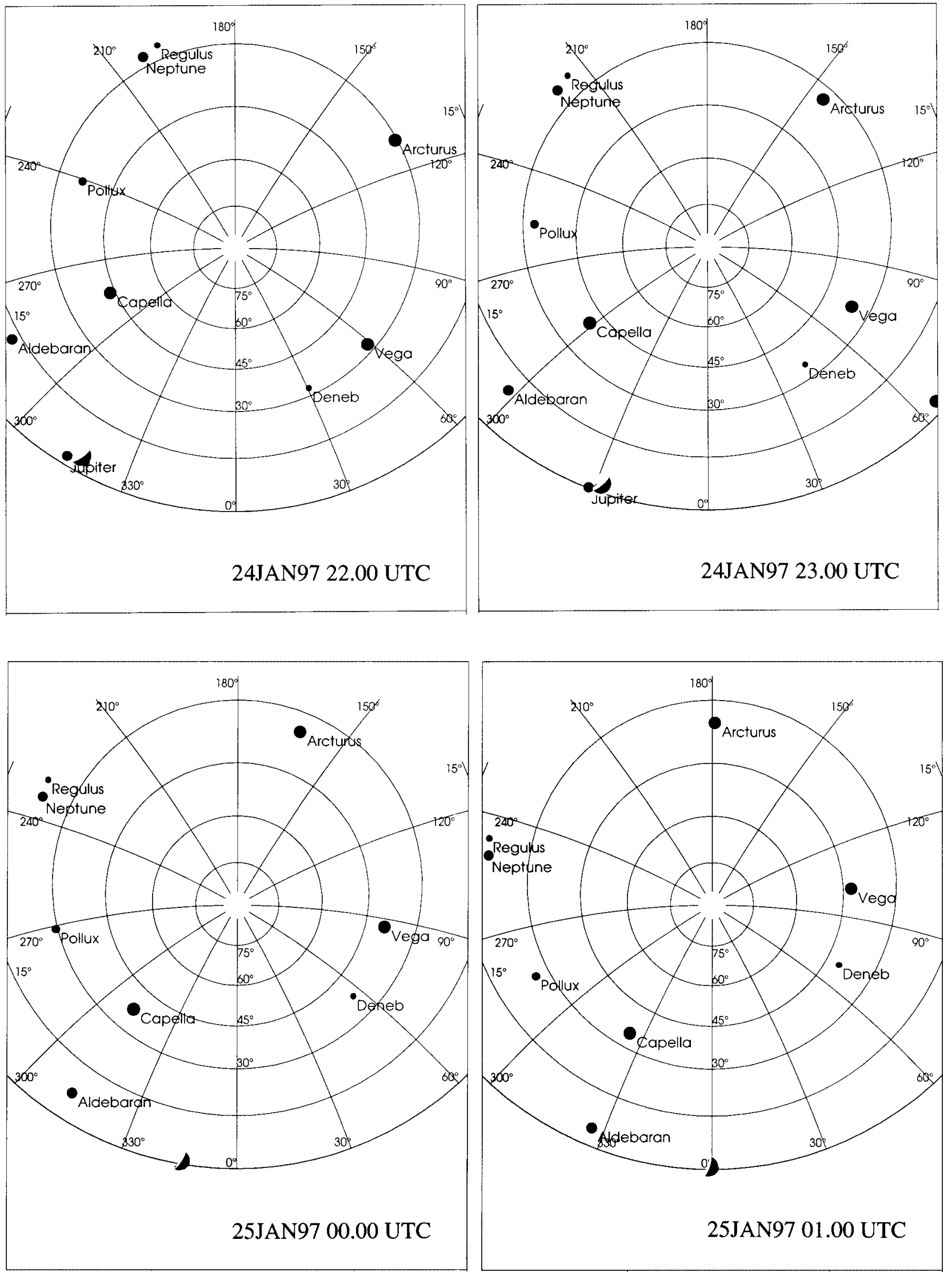

FIG. 2. The sky above Het Behouden Huys, looking towards the northern horizon. The altitude circles are centred around the local zenith. The positions of the stars, the planets, and the moon are shown for every hour from 24 January 22:00 UTC to 25 January 01:00 UTC, 1597 on Fig. 2a and from 25 January 02:00 UTC to 25 January 05:00 UTC, 1597 on Fig. 2b. The ecliptic conjunction occurred at 00:14 UTC with a geometric altitude of Jupiter of $-2^{\circ} 2^{\prime}$. The azimuthal conjunction took place at 02:30 UTC, when the geometric altitude of Jupiter was $-1^{\circ} 40^{\prime}$. 

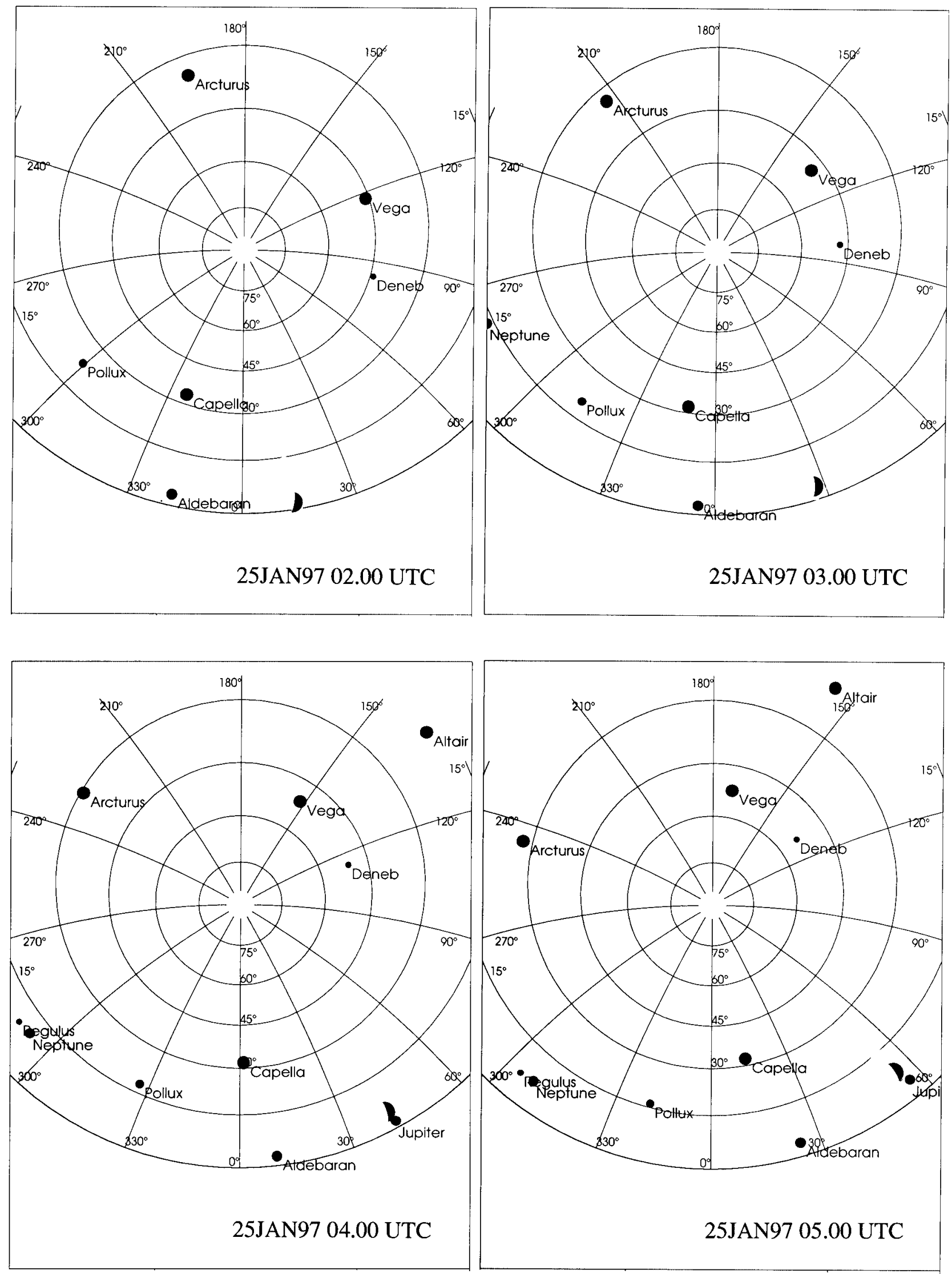

FIG. 2. cont'd. The sky above Het Behouden Huys, looking towards the northern horizon. The altitude circles are centred around the local zenith. The positions of the stars, the planets, and the moon are shown for every hour from 24 January 22:00 UTC to 25 January 01:00 UTC, 1597 on Fig. 2a and from 25 January 02:00 UTC to 25 January 05:00 UTC, 1597 on Fig. 2b. The ecliptic conjunction occurred at 00:14 UTC with a geometric altitude of Jupiter of $-2^{\circ} 2{ }^{\prime}$. The azimuthal conjunction took place at 02:30 UTC, when the geometric altitude of Jupiter was $-1^{\circ} 40^{\prime}$ 
TABLE 3. Altitude corrections ${ }^{1}$ at an apparent altitude of $0^{\circ} 0^{\prime}$.

\begin{tabular}{ll}
\hline \hline Refraction under standard conditions & $-34^{\prime}$ \\
Correction for $-30^{\circ} \mathrm{C}$ and $1050 \mathrm{mb}$ & $-10^{\prime 2}$ \\
Dip for $14.5 \mathrm{~m}$ eye height & $-07^{\prime}$ \\
& $-51^{\prime}$ \\
Correction for sun's centre & $-16^{\prime}$ \\
Semidiameter & $-1^{\circ} 07^{\prime}$ \\
\hline
\end{tabular}

${ }^{1}$ Data from the Nautical Almanac.

${ }^{2}$ Extrapolated from data in the Nautical Almanac.

\section{THE NOVAYA ZEMLYA EFFECT}

At local noon on 24 January 1597, the declination of the sun was $-19^{\circ} 11^{\prime}$. Using the now accurately known latitude of $76^{\circ} 15^{\prime}$, I calculate that it was still $5^{\circ} 26^{\prime}$ below the horizon. Table 3 gives the corrections relevant to an observation at an apparent altitude of $0^{\circ} 0^{\prime}$. The correction for astronomical refraction applies to normal atmospheric conditions, i.e., assuming that the density of the air and therewith the index of refraction, $n$, decrease monotonously with elevation.

The sum of the corrections for refraction and dip, without the minus sign, amounts to $51^{\prime}$ and equals therefore the amount by which the sun appears to be "lifted." Since the semidiameter of the sun subtends $16^{\prime}$, it is then clear that the upper limb of the sun becomes visible when its centre is less than $1^{\circ} 07^{\prime}$ below the horizon. That would have been on 9 February for the first time.

Nowadays we know the "special conditions" that Beke had to invoke to make the premature appearance of the sun occur. It is a sudden jump in the index of refraction, associated with a temperature inversion layer. Light that strikes this layer from below under near-parallel angles may be ducted by the layer through multiple reflections. If sunlight is captured by this duct, it may be guided along the inversion layer for as long as the duct persists. The effect bears some resemblance to the conduction of light inside a glass fibre and has been named the "Novaya Zemlya Effect." For a full description and references to documented observations of the effect, the reader is referred to the work of Lehn (Lehn, 1979; Lehn and German, 1981).

For a sun that is, say, $5^{\circ}$ below the horizon, the duct must exist over a length of at least 300 nautical miles. Such conditions may build up over an extended flat and cold surface, such as the frozen Kara Sea over which winterers at Het Behouden Huys looked out to the south. The duct itself appears to the observer as a greyish band extending upward from just a few minutes of arc to typically $10-20$ ' of arc above the horizon. When it extends over a sufficient length, the sun may become visible within its boundaries and may look rectangular or otherwise deformed in shape. The weather had been mostly fair, with clear skies and little wind since 18 January, when on 24 January the upper rim of the sun was seen by De Veer, Heemskerck, and another man. The "missing altitude" to be made good by the Novaya Zemlya effect is: $-\left(5^{\circ} 26^{\prime}-1^{\circ} 07^{\prime}\right)=-4^{\circ} 19^{\prime}$. This seems quite possible. On 25
January the skies were cloudy, but on 26 January De Veer reported a dark band just over the horizon which he thought prevented them from seeing the sun. This band may very well have been the duct. The fact that the sun was not seen may have been due to the insufficient length of the duct, or else the sun might have been obstructed by clouds, which often stretch as a thin layer just below the inversion layer.

On 27 January, the weather was fair and the sun was observed "in its full roundness" and free above the horizon. Thus its apparent altitude must have been at least 16'. The sun appeared round, and the window must have extended upwards to more than 32 , which is more than has ever been documented (Lehn, pers. comm. 1997). Also one would expect the sun to have shown distortions, which are not mentioned.

Although the fine weather with clear skies persisted on 28 January, no mention of the sun is made for that day. Then followed two days of dark weather with snowstorms. On 31 January, De Veer wrote that the sun was clear, but gave no details about its altitude or shape. One may infer that nothing struck them as peculiar in any way. A week of foul weather and snowstorms followed, interrupted only by a fair day on 3 February. However, it was misty then, and the sun was not seen.

The last day that the sun's upper limb should have stayed below the horizon was 8 February. De Veer reported that the sun was seen to rise in the SSE and set in the SSW. If we take it that it was the upper rim of the sun that appeared in the SSE and disappeared in the SSW, the sun's meridian altitude would normally have been about 45', and the window of the duct would have had to extend over $1^{\circ}$ above the horizon to make the upper limb fit inside it. This seems far too high for the upper boundary of the Novaya Zemlya duct. Rather, one would expect the sun to become visible in the SSE and creep along the horizon till it would disappear in the SSW.

One may wonder about the fact that distortions of the sun's shape were not reported. As sailors, the expedition members were familiar with the flattening of the rising and setting sun, and they would of course have still called it round when it had that familiar image. A rectangular shape or a split image would, however, have been noticed as uncommon. On the other hand, the light through the window of the duct might have been too bright to look straight into it (Lehn, pers. comm. 1997), so that they might not have noticed a possible deformation of the image. The same argument could explain why they noticed nothing irregular in the sun's path on 8 February. The next day, February 9, was again a fine clear day, but there was a haze in the south. Again this may have been the duct.

On 10 February, De Veer wrote that they were already beginning to feel the heat of the sun. This sensation was probably more psychological than physical: assuming the values of astronomical refraction and dip as in Table 3, one finds that the sun's lower limb just rides on the horizon at meridian passage.

The reported early observations of the sun are summarized in Table 4. The Novaya Zemlya effect seems to explain all 
TABLE 4. Survey of the premature appearances of the sun.

\begin{tabular}{llll}
\hline \hline Date & Declination & & $\begin{array}{l}\text { Geometrical } \\
\text { meridian altitude }\end{array}$ \\
& & Comment in journal \\
\hline 24 Jan $-19^{\circ} 11^{\prime}$ & $-5^{\circ} 26^{\prime}$ & Observation of upper rim \\
27 Jan $-18^{\circ} 26^{\prime}$ & $-4^{\circ} 41^{\prime}$ & Sun round and just free of horizon \\
31 Jan $-17^{\circ} 21^{\prime}$ & $-3^{\circ} 36^{\prime}$ & Clear sun \\
08 Feb $-14^{\circ} 57^{\prime}$ & $-1^{\circ} 12^{\prime}$ & Rise SSE, set SSW \\
\hline \hline
\end{tabular}

${ }^{1}$ From the program SkyMap.

${ }^{2}$ The geometrical meridian altitude is $90^{\circ}-\mathrm{LAT}+\mathrm{DEC}$, where LAT $=76^{\circ} 15^{\prime}$.

observations from 24 January to 8 February, though details like the great apparent height of the duct and the fact that no distortions are reported remain puzzling.

More difficult to understand is the observation of Jupiter, at the time of its ecliptic conjunction with the moon at 00:14 UTC on 25 January, at a true bearing of $347^{\circ} 28^{\prime}$, i.e., $12^{\circ} 32^{\prime}$ west from the true north. If the Novaya Zemlya effect is accepted as the explanation for the appearance of the sun on 24 January, the inversion layer most likely still existed during the night that followed. Having at that moment a geometrical altitude of $-2^{\circ} 2^{\prime}$, Jupiter could have easily been lifted up by the duct. However, in the direction of observation the landscape is not flat: the line of view leads over the northern edge of the central mountain ridge of the island. The land rises smoothly in that direction to a maximum height of about $400 \mathrm{~m}$ at a distance of about $45 \mathrm{~km}$ from Het Behouden Huys and drops again to sea level towards the northern coast. To the north and northeast of Het Behouden Huys the landscape is flat again, and the Novaya Zemlya effect might have made Jupiter appear well before its geometrical altitude became positive. In particular, Jupiter might have been visible at the time of the azimuthal conjunction at a true bearing of $19^{\circ} 22^{\prime}$ (east of north).

\section{DOUBTS ABOUT THE OBSERVATIONS AND OUTLOOK FOR VERIFICATION}

Although most of De Veer's descriptions of the sun's early return may be explained by the Novaya Zemlya Effect, yet some doubts remain. After their return, De Veer and Heemskerck were questioned by Robert Robertsz, who asked them about their timekeeping during the dark winter and suggested that they might very well have been off by two weeks. In his letter to William Blaeu (l' Honoré Naber, 1917 [2]:cxii; Beke, 1876:cxlv), Robertsz wrote that they could offer no more than a weak defense and only on the next day came up with the story of their observation of the MoonJupiter conjunction, which Robertsz then understandably discarded as an a posteriori construction.

The detail in which De Veer wrote about this conjunction is clearly in defense against the accusations of Robertsz. Their discussions took place shortly after De Veer's return and prior to the first edition of his book in 1598 (De Veer, 1598).
Today, four centuries later, we know that the Novaya Zemlya Effect exists, but we can still share some of Robertsz's reservations. For example, De Veer and Heemskerck claimed to have kept the time with the help of sand-glasses. Why did they not read the date from the phase of the moon? Even during the dark winter, the moon could be seen whenever its declination was less negative than $\mathrm{S} 13^{\circ} 45^{\prime}$, and above $\mathrm{N} 13^{\circ} 45^{\prime}$ it remained visible around the clock.

At the very time of the first sighting of the sun on 24 January 1597, the weather was clear and the moon must have been prominently visible in the ESE at an altitude of around $14^{\circ}$. It takes no great experience to read the age of the moon within one or two days. In fact, De Veer writes that the moon was then 8 days old, but he does not draw the obvious conclusion: they could have looked up the date of the new moon in Scala's book right away and found the date within two days.

It is true, of course, that the observation of the MoonJupiter conjunction gave the time with much greater precision, and this may have been the reason for observing it. Although the Novaya Zemlya effect seems to explain the early observations of the sun, these could equally well be explained if the journal dates between 24 January and 10 February were to be shifted by about two weeks. On 19 February, the altitude of the sun was measured as $3^{\circ} 16^{\prime}$, and from then on all dates appear to be correct, as we have shown above from our comparison of quoted and tabulated declinations.

If, on the other hand, we accept the Novaya Zemlya effect as the explanation for the premature appearances of the sun, we are led to conclude that the day-counting has been basically correct throughout. It appears then that De Veer was not a storyteller as he was thought to be: his logbook keeps very close to the truth. Let us suppose then that his account of the Moon-Jupiter conjunction is also right. There is no problem when the observation of the conjunction is understood as an interpolation between the situations where Jupiter was "normally" visible. But De Veer claims that the ecliptic conjunction itself was observed. This is most puzzling and at the same time challenging: no other recording of the Novaya Zemlya effect exists to date that has been made over a terrain that is not perfectly flat. However, the terrain is smooth and the inversion layer would have just followed its contours (G.P. Können, pers. comm. 1997). Computer simulations are called for to assess if the light-guiding properties of the duct survive under such distortions and, if so, whether Jupiter is bright enough to have been visible in the duct.

The ultimate proof would of course be an observation of the Novaya Zemlya effect at the location of Het Behouden Huys and in the direction just west from north. Such an observation might be attempted if a celestial body were to pass through the right geometrical altitude window of typically $-5^{\circ}$ to $-1^{\circ}$, corresponding to a declination window of $\mathrm{N} 12.5^{\circ}$ to $\mathrm{N} 8.5^{\circ}$. If Jupiter was sufficiently bright to be seen, then Venus, the moon, and the sun would also be good candidates. 
Jupiter will satisfy this condition from 30 May 1999 until 16 March 2000, from 24 August 2003 until 17 October 2003, from 23 March 2004 until 13 June 2004, and thereafter not again until 2011.

The moon makes two passes every month at the right altitude. The sun fits in the proper declination window twice a year for about 10 days, around mid-April and in the second half of August. Also for Venus two such periods, slowly shifting in time, exist every year.

Gerrit de Veer has left us his story of the three voyages to the north and of the many "strange and woonderfull" things that he and his companions saw. His account has in wide circles been considered as rather inaccurate, an opinion that may be heard even today. We find, however, that the explorers' day-counting was essentially correct, and the Novaya Zemlya effect most likely explains the early return of the sun. Confirmation of De Veer's claim that they could see Jupiter during its conjunction with the moon on 25 January 1597 would show that his account is indeed a "True and Perfect Description."

\section{ACKNOWLEDGEMENTS}

The author wishes to express his gratitude to W.F.J. Mörzer Bruyns, L. Hacquebord, W.H. Lehn, P. van Leunen, K. Knip, G.P. Können, H. van Veen, and H.W.A. de Bruyn for numerous and illuminating discussions.

\section{REFERENCES}

BARENTS, W. 1595. Nieuwe Beschryvinghe ende Caertboeck van de Middellandtsche Zee. Amsterdam: Cornelis Claesz.

BEKE, Ch.T. 1876. The three voyages of Willem Barents to the Arctic regions (1594, 1595 and 1596) by Gerrit De Veer, 1st ed. 1853. 2nd ed. with an Introduction by Lieut. Koolemans Beynen, 1876. Printed for the Hakluyt Society, London.

DAVIDS, C.A. 1985. Zeewezen en Wetenschap. Ph.D. Thesis, University of Leiden. Amsterdam/Dieren: De Bataafsche Leeuw.

De JONGE, J.K.J. 1872. Nova Zembla. 's Gravenhage: Martinus Nijhoff.

De MEDINA, P. 1545. Arte de Navigar. Valladolid, Spain. French translation by Nicolas de Nicolai, 1554: L'art de Naviguer.
Lyon: Guillaume Rouille. Facsimile edition. 1988. Milano: Ugo Mursia editore. Dutch translation by Michiel Coignet, 1580: De Zeevaert oft Conste van ter Zee te varen. Extended: met noch een ander nieuwe Onderwijsinghe op de principaelste puncten der Navigatien, Antwerp.

De VEER, G. 1598. Waerachtige Beschryvinge van drie seylagiën ter werelt noyt soo vreemt ghehoort. Amsterdam: Cornelis Claesz.

HONORÉ NABER, S.P. l'. 1917. Reizen van Willem Barents, Jacob van Heemskerck, Jan Cornelis Rijp en anderen naar het Noorden (1594-1597), Vols. 1 and 2. Publications by the Linschoten Vereniging, Vols. 14 and 15. 's Gravenhage: Martinus Nijhoff.

GAWRONSKI, J.H.G., BOYARSKY, P.V., VEKHOV, N.V., MAZOUROV, Yu.L., and FLOORE, P.M. 1997. Northbound with Barents. Russian-Dutch archeological research on the archipelago Novaya Zemlya. Amsterdam: Jan Mets.

GERRITZ, H. 1924. Histoire du Pays nommé Spitsberge. Publications by the Linschoten Vereniging Vol. 23. 's Gravenhage: Martinus Nijhoff.

LEHN, W.H. 1979 . The Novaya Zemlya effect: An arctic mirage. Journal of the Optical Society of America 69:776-781.

LEHN, W.H., and GERMAN, B.A. 1981. The Novaya Zemlya effect: Analysis of an observation. Applied Optics 20:20432047.

MARRIOTT, C.A. n.d. Computer program SkyMap, PC-version under Windows. Obtainable from the author at 9 Severn Road, Culcheth, Cheshire WA3 5ED, United Kingdom. Unregistered versions may be found on the WWW under Shareware.

MÖRZER BRUYNS, W.F.J. 1994. The cross-staff: History and development of a navigational instrument. Zutphen: Walburg Druk.

NAUTICAL ALMANAC. London: Her Majesty's Nautical Almanac Office. Edited yearly.

SCALA, I. 1589. Ephemeridae. Venice.

SCHIMPF, S. n.d. Computer program CyberSky, PC-version under Windows. Unregistered versions may be found on the WWW under Shareware.

STIMSON, A. 1988. The mariner's astrolabe: A survey of known, surviving sea astrolabes. Utrecht: HES Publishers.

VAN DER WERF, S.Y. 1996. Astronomische waarnemingen tijdens de derde tocht naar het Noorden (1596-1597). Reconstructie van de dagtelling en zoektocht naar het graf van Barents. In: Hacquebord, L., and van Leunen, P., eds. 400 Jaar Willem Barentsz. Harlingen: Flevodruk Harlingen. 93-101. 